\title{
In vitro a-Glucosidase and a-Amylase Activities of Wild and Cultivated Amaranthus spp. and Isolated Compounds
}

\author{
Nolitha Nkobole ${ }^{1, *}$, Olusola Bodede', Ahmed A Hussein², Gerhard Prinsloo'
}

\section{Nolitha Nkobole ${ }^{1, *}$, Olusola Bodede', Ahmed A Hussein ${ }^{2}$, Gerhard Prinsloo ${ }^{1}$}

'Department of Agriculture and Animal Health, University of South Africa, Science campus, Florida, SOUTH AFRICA.

${ }^{2}$ Department of Chemistry, Cape Peninsular University of Technology, Symphony Way, Bellville, Western Cape, SOUTH AFRICA.

\section{Correspondence}

Nolitha Nkobole

Department of Agriculture and Animal

Health, University of South Africa, Science campus, Florida, SOUTH AFRICA.

E-mail: nkobon@unisa.ac.za

\section{History}

- Submission Date: 11-10-2021;

- Review completed: 08-11-2021;

- Accepted Date: 15-11-2021.

DOI : 10.5530/pj.2021.13.208

Article Available online

http://www.phcogj.com/v13/i6

Copyright

(C) 2021 Phcogj.Com. This is an openaccess article distributed under the terms of the Creative Commons Attribution 4.0 International license.

\begin{abstract}
Introduction: Diabetes mellitus is a serious metabolic disorder that affects many South Africans. There is urgent need for alternative and affordable diabetic therapy from edible wild plants which have been used by the indigenous people for many years. This study presents in vitro antidiabetic effects of methanol leaf extracts of wild and cultivated Amaranthus spp. and isolated compounds. Methods: The inhibitory effects against yeast $\alpha$-glucosidase and porcine $\alpha$-amylase were determined using a dilution series of ethanolic extracts of wild and cultivated leaf extracts and isolated compounds of Amaranthus spp. The aerial parts of the plant material were subjected to silica gel chromatography to yield three compounds. Results: Wild A. hybridus showed potent a-glucosidase enzyme activity $(89.92 \pm 0.04 \%)$ at the lowest concentration tested $(0.125 \mathrm{mg} / \mathrm{mL})$ in comparison to acarbose which exhibited $80.20 \pm 0.13 \%$ inhibition at the same concentration. Cultivated $A$. cruentus extracts inhibited a-glucosidase enzyme activity $(84.95 \pm 0.04 \%)$ at the lowest concentration compared to cultivated $A$. hybridus which exhibited inhibitory activities of 72.28 $\pm 0.06 \%$. In addition, three compounds namely, a-spinasterol, palmitic acid and pheophorbide A-methyl ester isolated from wild A.cruentus were tested for in vitro antidiabetic activity. Palmitic acid demonstrated the highest inhibition against $\alpha$-glucosidase for all the concentrations tested. Tested separately, the isolated compounds were weaker a-amylase enzyme inhibitors however, when the compounds were combined, inhibition of $\alpha$-amylase increased to $58.49 \pm 002 \%$ at $0.5 \mathrm{mg} / \mathrm{mL}$. Conclusions: Extracts and compounds of Amaranthus showed strong $\alpha$-glucosidase activity inhibition and mild a-amylase activity inhibition suggesting that the extracts and compounds slow glucose absorption.

Key words: a-Amylase; $\boldsymbol{\alpha}$-glucosidase; Blood glucose; Diabetes mellitus; Hyperglycemia; Phytochemicals.
\end{abstract}

\section{INTRODUCTION}

Amaranthus cruentus L and Amaranthus hybridus $\mathrm{L}$ which are commonly known as pigweed are widely consumed in South Africa ${ }^{1}$ and have, in recent years, garnered interest in the academic community due to their nutritional profile. There is also overwhelming evidence supporting the medicinal claims associated with the use of Amaranth, thus there is a perceived increasing demand for the crop. For an example, the leaves of Amaranthus hybridus $\mathrm{L}$ are used in folk medicine for the treatment of diabetes in southern India ${ }^{2}$. Furthermore, A. cruentus has been reported to treat diabetes in many parts of Zambia ${ }^{3}$.

Diabetes mellitus (DM) is a serious, long-term disease that has a significant impact on the lives and well-being of individuals, communities and societies around the world ${ }^{4}$. Pathogenesis of diabetes leads to adverse health problems, such as neuropathy, retinopathy and cardiovascular disorders ${ }^{5}$. Numerous pharmacological agents having a diverse mode of action are being used for the cure and management of $\mathrm{DM}^{6}$. While hormonal therapy is effective for the treatment of DM, its use is limited due to its limited actions and adverse side effects including hypoglycemia, weight loss, abdominal pain, liver damage, loss of appetite, lactic acidosis and diarrhea ${ }^{7,8}$. The other diabetes mellitus management strategy is based on the reduction of glucose absorption by interference in the activity of $\alpha$-glucosidase and $\alpha$-amylase (carbohydrate-hydrolyzing enzymes) ${ }^{9}$. a-Amylase hydrolyses oligosaccharides to polysaccharides, while $\alpha$-glucosidase catalyzes the last step of carbohydrate hydrolysis leading to the production of absorbable monosaccharides ${ }^{10}$. To date, only a limited number of $\alpha$-glucosidase and a-amylase inhibitors are commercially available; perhaps because their synthesis is very complex, and serious gastrointestinal complications have also been reported to be associated with their use ${ }^{11}$.

Alternatively, food plants with promising therapeutic potential and limited side effects are now getting a lot of publicity and recognition for DM management. Studies have demonstrated that plant-based foods that naturally contain polyphenolic compounds and flavonoids have been linked to in vitro inhibitory activities of intestinal $\alpha$-glucosidase and pancreatic $\alpha$-amylase ${ }^{12-14}$. Some of the mostly consumed wild vegetables in South Africa have also played a vital role in the fight against DM. Cleome gynandra and Citrullus lanatus for an example were found to be potent intestinal $\alpha$-glucosidase and pancreatic $a$-amylase inhibitors ${ }^{15,16}$ while Corchorus olitorius showed higher $\alpha$-amylase inhibitory ability ${ }^{17,18}$. Amaranthus spp. in particular has been subject to investigation and proved effective against $\mathrm{DM}^{19-22}$.

Efforts should be made to promote the cultivation of Amaranth in order to meet the growing demand, provided that accurate and sufficient information is available on the health and medicinal effects of the plants. Thus, the aim of the current study was to evaluate the in vitro inhibitory effects of wild and cultivated Amaranthus leaf extracts and isolated constituents on the activities of selected diabetic related carbohydrates metabolizing enzymes, $\alpha$-amylase and $\alpha$-glucosidase. 


\section{MATERIALS AND METHODS}

\section{Chemicals}

a-Glucosidase (Saccharomyces cerevisiae), a-amylase (porcine pancreas), 3, 5, di-nitro salicylic acid (DNS), P-nitro-phenyl- $\alpha-\mathrm{D}$ glucopyranoside ( $\mathrm{p}-\mathrm{NPG})$, sodium carbonate $\left(\mathrm{Na}_{2} \mathrm{CO}_{3}\right)$, sodium dihydrogen phosphate, di-sodium hydrogen phosphate, acarbose and potato starch, were purchased from Merck, South Africa.

\section{Collection of plant materials}

Collection of wild vegetables from KwaZulu-Natal (KZN) Province, South Africa

Amaranthus hybridus L. leaves were bought from Esikhawini informal market during the month of April of 2018. Esikhawini is a periurban settlement situated in the district of Richards bay in KwaZuluNatal. The area is characterized by $1087 \mathrm{~mm}$ of rain per year, with most rainfall occurring mainly during summer. Esikhawini receives the lowest rainfall in June $(42 \mathrm{~mm})$ and the highest in March (133 $\mathrm{mm}$ ) (Esikhawini climate, Map of South Africa, ND) ${ }^{23}$. The leaves of Amaranthus cruentus L. were purchased from Stanger which is situated in KwaDukuza. Stanger normally receives about $866 \mathrm{~mm}$ of rain per year, most of which occurs during the summer (Stanger climate, Map of South Africa, ND) $)^{24}$. Wild Amaranth plants collected from KwaZulu-Natal were confirmed by Prof. Alfred Zobolo, a botanist at the University of Zululand.

\section{Planting of $A$. cruentus and $A$. hybridus}

Amaranthus cruentus and A. hybridus were grown in November of 2017 at Mothong African Heritage Trust garden in Mamelodi, Pretoria (GPS co-ordinates: $25^{\circ} 41^{\prime} 49.7^{\prime \prime} \mathrm{S} 28^{\circ} 20^{\prime} 17.4^{\prime \prime} \mathrm{E}$ ) a community-based project interested in cultivation of African leafy vegetables (ALVs) and medicinal plants. The seeds were donated by the Agriculture Research Council-Vegetable and Ornamental Plants (ARC-VOP). Prior to planting, the seeds were sown in 98 cavity seedling trays using hygromix as a growth medium and kept under a $40 \%$ shade net. Seedlings were transplanted to the field 21 days after emergence. The trial was planted with a spacing of $10 \mathrm{~cm} \times 20 \mathrm{~cm}\left(50 \text { plants } \mathrm{m}^{-2}\right)^{25}$. Limestone ammonium nitrate (LAN) (containing 28\% nitrogen, calcium and magnesium) fertilizer was applied on the freshly prepared soil on the day of planting the seedlings. Plants were irrigated once a week.

\section{Extraction and purification of chemical constituents}

For the analysis of extracts, fifty grams $(50 \mathrm{~g})$ of dried plant materials were ground to a fine powder. Each plant sample was soaked overnight at room temperature in $50 \mathrm{~mL}$ of $100 \%$ methanol $(\mathrm{MeOH})$. The solvent was then removed and replaced with the same solvent volume. This procedure was repeated two times. Extracts were filtered and concentrated to dryness under reduced pressure using a rotary evaporator (BUCHI-Labotech, Switzerland). Dried extracts were stored in the dark at room temperature until analysis.

The aerial parts of the plant material $(1 \mathrm{~kg})$ were blended and extracted with methanol and water mixture $(80: 20)(5 \mathrm{~L})$ at room temperature $(25$ $\left.{ }^{\circ} \mathrm{C}\right)$ for $24 \mathrm{~h}$. The methanolic water extract was filtered and evaporated to dryness under reduced pressure at $40^{\circ} \mathrm{C}$ to yield $63.9 \mathrm{~g}(6.39 \%)$. The total extract $(63.9 \mathrm{~g})$ was applied to a silica gel column $(10 \times 20 \mathrm{~cm})$ and eluted using a gradient of hexane (Hex) and ethyl acetate (EtOAc) in order of increasing polarity: 36 fractions $(500 \mathrm{~mL}$ each) were collected and combined according to their TLC profiles to yield thirteen fractions. Out of the thirteen combined fractions, fraction one yielded two compounds, palmitic acid $(22.2 \mathrm{mg})$ and $\alpha$-spinosterol $(48.9$ $\mathrm{mg}$ ). In addition, fraction four yielded one compound, pheophorbide A-methyl ester $(124 \mathrm{mg})$, a derivative of chlorophyll which was isolated from $A$. cruentus for the first time.

\section{In vitro antidiabetic assays}

\section{a-Glucosidase inhibitory activity}

The inhibitory activity of plant extracts against intestinal $\alpha$-glucosidase was determined following the method proposed by Telagari and Hullatti ${ }^{5}$. The concentration of plant extracts ranged from 0.125 to 2 $\mathrm{mg} / \mathrm{mL}$. A negative control was prepared using the same procedure however, the plant extract was replaced with phosphate buffer (100 $\mathrm{mM}, \mathrm{pH}=6.8)$. A reaction mixture containing $50 \mu \mathrm{L}$ phosphate buffer, $10 \mu \mathrm{L}$ alpha-glucosidase $(1 \mathrm{U} / \mathrm{mL})$, and $20 \mu \mathrm{L}$ of varying extract concentrations was pre-incubated at $37{ }^{\circ} \mathrm{C}$ for 15 minutes in a 96well plate. Acarbose (positive control) and isolated compounds were tested at varying concentrations from $0.062-1 \mathrm{mg} / \mathrm{mL}$. In addition, $20 \mu \mathrm{L}$ P-NPG $(5 \mathrm{mM})$ was then added as a substrate and further incubated at $37^{\circ} \mathrm{C}$ for $20 \mathrm{~min}$. The reaction was stopped with the addition of $50 \mu \mathrm{L}$ $\mathrm{Na}_{2} \mathrm{CO}_{3}(0.1 \mathrm{M})$. The assay was performed in triplicate. The absorbance of the released p-nitrophenol was measured at $405 \mathrm{~nm}$ with a Thermo Scientific Varioskan Flash Spectrophotometer. The results were expressed as percentage inhibition, which was calculated using the formula,

Inhibitory activity $(\%)=(1-$ As/Ac $) \times 100$

Where,

As is the absorbance in the presence of test substance and Ac is the absorbance of control.

\section{a-Amylase inhibitory activity}

The assay was adapted from Telagari and Hullatti ${ }^{5}$ wherein the concentration of plant extracts ranged from 0.125 to $2 \mathrm{mg} / \mathrm{mL}$. The concentrations of the positive drug control Acarbose and isolated compounds ranged from $0.062-1 \mathrm{mg} / \mathrm{mL}$. A negative control was prepared using the same procedure however, the plant extract was replaced with phosphate buffer $(100 \mathrm{mM}, \mathrm{pH}=6.8)$. The reaction mixture containing $50 \mu \mathrm{L}$ phosphate buffer, $10 \mu \mathrm{L} \alpha$-amylase $(2 \mathrm{U} /$ $\mathrm{mL}$ ), and $20 \mu \mathrm{L}$ extract was pre-incubated for 20 minutes at $37^{\circ} \mathrm{C}$ in a 96-well plate. One percent of a soluble potato starch $(100 \mathrm{mM}$ phosphate buffer $\mathrm{pH}$ 6.8) was then incorporated as a substrate and further incubated at $37^{\circ} \mathrm{C}$ for 30 minutes. A colour reagent, DNS (100 $\mu \mathrm{L}$ ) was then added and boiled for 10 minutes. The absorbance of the resulting mixture was measured at $540 \mathrm{~nm}$ using a Thermo Scientific Varioskan Flash Spectrophotometer. The results were expressed as percentage inhibition, which was calculated using the formula,

Inhibitory Activity $(\%)=(1-$ As/Ac $) \times 100$

\section{Statistical analysis}

All the analyses were carried out in triplicate and the results are expressed in mean \pm SD. All of the data analyses were carried out using Microsoft Excel 2010. Moreover, $\mathrm{IC}_{50}$ for the extract was calculated by plotting extract concentration against $\%$ inhibition. The $\mathrm{IC}_{50}$ values were only calculated for only wild $A$. cruentus since all the other samples and a positive control showed activity beyond $50 \%$.

\section{RESULTS}

\section{Chemical characterization of the isolated compounds}

All the structures of isolated compounds (1-3) are illustrated in Figure 1. Identification of the isolated compounds was achieved by comparing their spectroscopic data with those reported in literature. All the NMR data of all isolated compounds are illustrated in the Supplementary material.

\section{Characterization of $\alpha$-spinasterol (1)}

A colorless crystalline solid. ${ }^{1} \mathrm{H}-\mathrm{NMR}\left(\mathrm{CDCl}_{3}, 600 \mathrm{MHz}\right): 0.53(3 \mathrm{H}, \mathrm{s}$, H-18), 0.78-0.79 (6H, m, H-27, H-29), 0.83 (3H, s, H-19), 0.84 (3H, d, J 


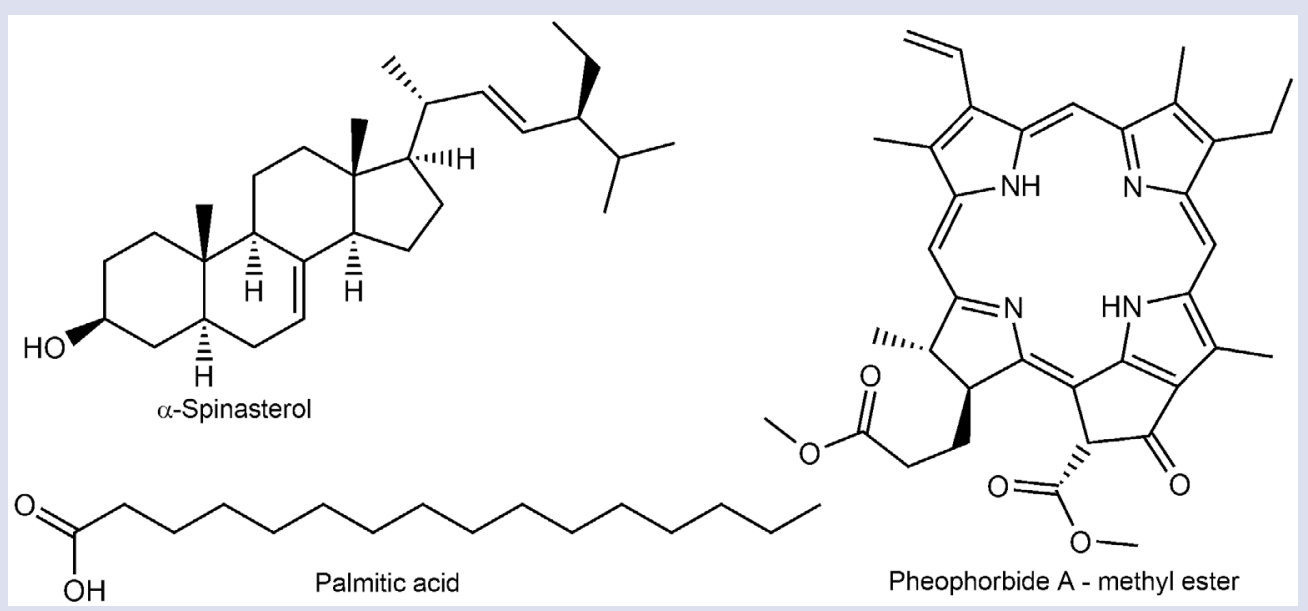

Figure 1: Chemical structures of isolated compounds.

Table 1: Effect of plant extracts and isolated compounds on the inhibition of a-glucosidase enzyme.

\begin{tabular}{lccccccc}
\hline $\begin{array}{l}\text { a-glucosidase }(\% \\
\text { inhibition) }\end{array}$ & $\begin{array}{c}\mathrm{IC}_{50} \\
\mathrm{mg} / \mathrm{mL}\end{array}$ & $0.062 \mathrm{mg} / \mathrm{mL}$ & $0.125 \mathrm{mg} / \mathrm{mL}$ & $0.25 \mathrm{mg} / \mathrm{mL}$ & $0.5 \mathrm{mg} / \mathrm{mL}$ & $1 \mathrm{mg} / \mathrm{mL}$ & $2 \mathrm{mg} / \mathrm{mL}$ \\
\hline A.cruentus wild & 0.144 & $\mathrm{~N} / \mathrm{T}$ & $41.85 \pm 0.10$ & $55.96 \pm 0.13$ & $61.85 \pm 0.13$ & $78.12 \pm 0.34$ & $87.13 \pm 0.18$ \\
A. cruentus, cultivated & $\mathrm{ND}$ & $\mathrm{N} / \mathrm{T}$ & $84.95 \pm 0.09$ & $85.46 \pm 0.07$ & $81.63 \pm 0.02$ & $77.40 \pm 0.11$ & $61.61 \pm 0.05$ \\
A. hybridus wild & $\mathrm{ND}$ & $\mathrm{N} / \mathrm{T}$ & $89.92 \pm 0.04$ & $93.98 \pm 0.03$ & $90.91 \pm 0.24$ & $96.32 \pm 0.05$ & $97.10 \pm 0.05$ \\
A. hybridus, cultivated & $\mathrm{ND}$ & $\mathrm{N} / \mathrm{T}$ & $72.28 \pm 0.06$ & $76.59 \pm 0.23$ & $67.11 \pm 0.25$ & $79.19 \pm 0.13$ & $63.85 \pm 0.16$ \\
a-Spinasterol & $\mathrm{ND}$ & $67.41 \pm 0.10$ & $70.82 \pm 0.02$ & $72.91 \pm 0.04$ & $61.13 \pm 0.08$ & $80.06 \pm 0.04$ & $\mathrm{~N} / \mathrm{T}$ \\
Palmitic acid & $\mathrm{ND}$ & $91.26 \pm 0.01$ & $89.67 \pm 0.06$ & $90.51 \pm 0.01$ & $85.92 \pm 0.02$ & $83.26 \pm 0.03$ & $\mathrm{~N} / \mathrm{T}$ \\
$\begin{array}{l}\text { Pheophorbide } \\
\text { A-methyl ester }\end{array}$ & $\mathrm{ND}$ & $53.16 \pm 0.43$ & $68.08 \pm 0.30$ & $70.78 \pm 0.11$ & $75.41 \pm 0.03$ & $65.22 \pm 0.06$ & $\mathrm{~N} / \mathrm{T}$ \\
Acarbose & $\mathrm{ND}$ & $72.72 \pm 0.24$ & $80.20 \pm 0.13$ & $73.41 \pm 0.16$ & $66.31 \pm 022$ & $68.18 \pm 011$ & $\mathrm{~N} / \mathrm{T}$
\end{tabular}

NT: not tested

ND: not determined

Table 2: Effect of plant extracts and isolated compounds on the inhibition of a-amylase enzyme.

\begin{tabular}{|c|c|c|c|c|c|c|}
\hline a-amylase (\% inhibition) & $0.062 \mathrm{mg} / \mathrm{mL}$ & $0.125 \mathrm{mg} / \mathrm{mL}$ & $0.25 \mathrm{mg} / \mathrm{mL}$ & $0.5 \mathrm{mg} / \mathrm{mL}$ & $1 \mathrm{mg} / \mathrm{mL}$ & $2 \mathrm{mg} / \mathrm{mL}$ \\
\hline A. cruentus wild & $\mathrm{N} / \mathrm{T}$ & $34.70 \pm 0.17$ & $39.63 \pm 0.05$ & $34.25 \pm 0.05$ & $31.62 \pm 0.01$ & $23.47 \pm 0.02$ \\
\hline A. cruentus, cultivated & $\mathrm{N} / \mathrm{T}$ & $30.46 \pm 0.07$ & $25.57 \pm 0.14$ & $23.39 \pm 0.12$ & $19.74 \pm 0.14$ & $24.03 \pm 0.12$ \\
\hline A. hybridus, wild & $\mathrm{N} / \mathrm{T}$ & $5.67 \pm 0.04$ & $20.56 \pm 0.06$ & $22.20 \pm 0.03$ & $18.87 \pm 0.05$ & $27.47 \pm 0.13$ \\
\hline A. hybridus, cultivated & $\mathrm{N} / \mathrm{T}$ & $33.18 \pm 0.14$ & $13.29 \pm 0.11$ & $15.24 \pm 0.23$ & $24.58 \pm 0.46$ & $-7.55 \pm 0.29$ \\
\hline$\alpha$-Spinasterol & $27.73 \pm 0.17$ & $22.86 \pm 0.10$ & $28.22 \pm 0.12$ & $13.06 \pm 0.23$ & $43.37 \pm 0.15$ & $\mathrm{~N} / \mathrm{T}$ \\
\hline Palmitic acid & $18.68 \pm 0.07$ & 21.340 .08 & $25.05 \pm 0.02$ & $21.99 \pm 0.03$ & $21.16 \pm 0.07$ & $\mathrm{~N} / \mathrm{T}$ \\
\hline $\begin{array}{l}\text { Pheophorbide A-methyl } \\
\text { ester }\end{array}$ & $49.84 \pm 0.04$ & $11.50 \pm 0.19$ & $7.23 \pm 0.12$ & $14.15 \pm 0.15$ & $23.31 \pm 0.40$ & $\mathrm{~N} / \mathrm{T}$ \\
\hline Combined compounds & $57.45 \pm 0.04$ & $49.32 \pm 0.04$ & $48.69 \pm 0.05$ & $58.49 \pm 0.02$ & $53.65 \pm 0.04$ & $\mathrm{~N} / \mathrm{T}$ \\
\hline Acarbose & $71.37 \pm 0.01$ & $83.41 \pm 0.01$ & $86.29 \pm 0.02$ & $87.22 \pm 0.04$ & $89.00 \pm 0.05$ & $\mathrm{~N} / \mathrm{T}$ \\
\hline
\end{tabular}

\section{NT: not tested}

$=6.0 \mathrm{~Hz}, \mathrm{H}-26), 1.01(3 \mathrm{H}, \mathrm{d}, J=6.5 \mathrm{~Hz}, \mathrm{H}-21), 3.58(1 \mathrm{H}, \mathrm{m}, \mathrm{H}-3), 5.01$ $(1 \mathrm{H}, \mathrm{dd}, J=15.0,8.5 \mathrm{~Hz}, \mathrm{H}-23), 5.12(1 \mathrm{H}, \mathrm{m}, \mathrm{H}-7), 5.15(1 \mathrm{H}, \mathrm{dd}, J=$ 15.0, $8.5 \mathrm{~Hz}, \mathrm{H}-22) .{ }^{13} \mathrm{C}-\mathrm{NMR}\left(\mathrm{CDCl}_{3}, 600 \mathrm{MHz}\right): 12.05$ (C-18), 12.22 (C-29), 13.02 (C-19), 19.00 (C-27), 21.06 (C-21), 21.37 (C-26), 21.56 (C-11), 23.02 (C-15), 25.38 (C-28), 28.48 (C-16), 29.69 (C-6), 31.48 (C-2), 31.87 (C-25), 34.23 (C-10), $37.16(\mathrm{C}-1), 38.00(\mathrm{C}-4), 39.48(\mathrm{C}-$ 12), 40.29 (C-5), 40.78 (C-20), 43.30 (C-13), 49.48 (C-9), 51.26 (C-24), 55.13 (C-14), 55.94 (C-17), 71.06 (C-3), 117.45 (C-7), 129.47 (C-23), 138.14 (C-22), 139.57 (C-8).

Characterization of palmitic acid (2)

A slightly yellow coloured oily like semisolid compound. ${ }^{1} \mathrm{H}-\mathrm{NMR}$ $\left(\mathrm{CDCl}_{3}, 600 \mathrm{MHz}\right): 0.86(3 \mathrm{H}, \mathrm{t}, J=6.7), 1.26\left(28 \mathrm{H}\right.$, overlapping $\left.\mathrm{CH}_{2}\right)$, $2.33(2 \mathrm{H}, \mathrm{t}, J=6.7) .{ }^{13} \mathrm{C}-\mathrm{NMR}\left(\mathrm{CDCl}_{3}, 600 \mathrm{MHz}\right): 14.67,22.66 ; 24.68$, 29.05, 29.22, 29.33, 29.41, 29.57, 29.57, 29.61, 29.63, 29.64, 29.66, 29.67, $31.90,34.00,179.69$.
Characterization of pheophorbide A-methyl ester (3)

Pheophorbide A-methyl ester, a dark-green amorphous solid. ${ }^{1} \mathrm{H}-\mathrm{NMR}$ $\left(\mathrm{CDCl}_{3}, 600 \mathrm{MHz}\right): 1.65(3 \mathrm{H}, \mathrm{t}, J=7.8 \mathrm{~Hz}, \mathrm{H}-31), 1.81(3 \mathrm{H}, \mathrm{d}, J=7.2$ Hz, H-25), 2.31 (2H, m, H-2), 2.53 (2H, m, H-1), 3.15 (3H, s, H-29), 3.36 (3H, s, H-26), 3.57 (3H, s, H-36), $3.59(2 \mathrm{H}, \mathrm{q}, J=7.6 \mathrm{~Hz}, \mathrm{H}-30)$, $3.65(3 \mathrm{H}, \mathrm{s}, \mathrm{H}-32), 3.87(3 \mathrm{H}, \mathrm{s}, \mathrm{H}-34), 4.20(1 \mathrm{H}, \mathrm{m}, \mathrm{H}-3), 4.45(1 \mathrm{H}$, dq, $J=7.2,1.8 \mathrm{~Hz}, \mathrm{H}-4), 6.12(1 \mathrm{H}, \mathrm{dd}, J=11.4,1.2 \mathrm{~Hz}, \mathrm{Ha}-28), 6.14$ $(1 \mathrm{H}, \mathrm{dd}, J=17.9,1.2 \mathrm{~Hz}, \mathrm{Hb}-28), 6.24(1 \mathrm{H}, \mathrm{s}, \mathrm{H}-21), 7.92(1 \mathrm{H}, \mathrm{dd}, J=$ 17.9, $11.4 \mathrm{~Hz}, \mathrm{H}-27), 8.53(1 \mathrm{H}, \mathrm{s}, \mathrm{H}-6), 9.28(1 \mathrm{H}, \mathrm{s}, \mathrm{H}-11), 9.44(1 \mathrm{H}, \mathrm{s}$, $\mathrm{H}-16) .{ }^{13} \mathrm{C}-\mathrm{NMR}\left(\mathrm{CDCI}_{3}, 600 \mathrm{MHz}\right): 11.13$ (C-29), 12.02 (C-26), 12.05 (C-32), 17.33 (C-31), 19.38 (C-30), 23.03 (C-25), 29.63 (C-2), 31.06 (C1), 50.10 (C-4), 51.13 (C-3), 51.61 (C- 36), 52.79 (C-34), 64.70 (C-21), 93.08 (C-6), 97.48 (C-11), 104.36 (C-16), 105.26 (C-22), 122.69 (C- 28), 128.93 (C-19), 129.00 (C-27), 129.02 (C-18), 131.80 (C-8), 136.14 (C9), 136.19 (C-10), 136.48 (C-13), 137.91 (C-17), 142.03 (C-7), 145.15 
(C- 14), 149.64 (C-24), 150.91 (C-15), 155.58 (C-12), 161.18 (C-23), 169.54 (C-33), 172.14 (C-5), 173.30 (C-35), 189.56 (C-20).

\section{a-Glucosidase inhibitory activity}

Wild A. hybridus and cultivated A. cruentus showed strong inhibitory activities when compared to the positive control Acarbose (Table 1). The inhibition percentage of extracts against $\alpha$-glucosidase enzyme ranged from $61.61 \pm-97.10 \pm \%$ to $97.10 \pm 0.05 \%$ at the highest concentration tested $(2 \mathrm{mg} / \mathrm{mL})$. The extracts of wild grown A. cruentus showed weakest inhibition $(41.85 \pm 0.10 \%)$ against $\alpha$-glucosidase at the lowest concentration tested $(0.125 \mathrm{mg} / \mathrm{mL})$ whereas wild grown $A$. hybridus showed potent inhibition $(89.92 \pm 0.04 \%)$ at the same concentration. Acarbose, which was used as a standard reference drug exhibited $80.20 \pm 0.13 \%$ and $72.72 \pm 0.24 \%$ inhibition against $\alpha$-glucosidase at $0.125 \mathrm{mg} / \mathrm{mL}$ and $0.062 \mathrm{mg} / \mathrm{mL}$ respectively (Table 1 ). All isolated compounds inhibited a-glucosidase enzyme beyond 50\%. Palmitic acid showed the highest inhibitory activity towards $\alpha$-glucosidase at $83.26 \pm 0.03 \%$ and $91.26 \pm 0.01 \%$ at both high and low concentrations respectively.

\section{a-Amylase Inhibitory Activity}

In vitro a-amylase inhibitory results demonstrated that none of the crude Amaranthus spp. leaf extracts screened inhibited pancreatic a-amylase beyond $50 \%$ (Table 2). The percent inhibition of all tested extracts ranged from $-7.55 \pm 0.29$ to $34.70 \pm 0.17 \%$ at $2 \mathrm{mg} / \mathrm{mL}$ and $0.125 \mathrm{mg} / \mathrm{mL}$ respectively. Amongst the cultivated species, although not significant, A. cruentus had the highest $\alpha$-amylase inhibition of $23.47 \pm 0.02 \%$ at $2 \mathrm{mg} / \mathrm{mL}$. Wild grown $A$. cruentus had the highest a-amylase inhibition of $34.70 \pm 0.17 \%$ at $0.125 \mathrm{mg} / \mathrm{mL}$ compared to wild A. hybridus which only inhibited $\alpha$-amylase enzyme by $5.67 \pm 0.04 \%$. Acarbose, a known antidiabetic drug, had an enzyme inhibition ranging from $71.37 \pm 0.01(0.062 \mathrm{mg} / \mathrm{mL})$ to $89.00 \pm 0.05 \%(1 \mathrm{mg} / \mathrm{mL})$ (Table 2). $\alpha$-Spinosterol, palmitic acid and pheophorbide A-methyl ester were tested as individual compounds and none of these isolated compounds inhibited $\alpha$-amylase enzyme beyond $50 \%$. On the contrary, when the compounds were combined and tested against the activity of $\alpha$-amylase, the compounds showed $\alpha$-amylase inhibition $(58.49 \pm 002 \%)$ at $0.5 \mathrm{mg} / \mathrm{mL}$. At the same concentration $(0.5 \mathrm{mg} / \mathrm{mL})$, Acarbose, a positive antidiabetic drug, exerted the high inhibitory activity of $87.22 \pm 004 \%$ (Table 2).

\section{DISCUSSION}

Amaranth is widely used for its nutritional as well as medicinal properties, including its antidiabetic activity. The effect of genetic makeup and geographical distribution, however have not received attention, which is crucial for promoting cultivation of Amaranth species to improve nutritional status amongst communities.

This study is the first report on A. hybridus's high a-glucosidase inhibitory activity. The highest $\alpha$-glucosidase enzyme activity observed in A. cruentus in this study is in tandem with the work reported by $\mathrm{Oboh}^{26}$ where A. cruentus inhibited $\alpha$-glucosidase activity in vitro. Other species of Amaranthus have also been evaluated for a-glucosidase inhibitory activity. For example; the methanol extract of A. spinosus was a strong $\alpha$-glucosidase inhibitor at $8.49 \mu \mathrm{M} / \mathrm{mL}^{27}$. This study also compared the behavior of wild and cultivated Amaranthus spp. on a-glucosidase enzyme inhibition. Wild A. cruentus was less active at lowest concentration compared to its cultivated counterpart with inhibitory activities of $41.85 \pm 0.10 \%$ and $84.95 \pm 0.09$ at $0.125 \mathrm{mg} /$ $\mathrm{mL}$ respectively. The effective dose required for wild $A$. cruentus was concentration dependent which meant that the plant's effectiveness increased with an increase in concentration. As a result, it was possible to calculate the plant's $\mathrm{IC}_{50}=0.144 \mathrm{mg} / \mathrm{mL}$. This was not the case with cultivated $A$. cruentus. There was no relationship between the concentration level and inhibition which means, as the concentrations of cultivated $A$. cruentus increased, the enzyme inhibition presented no increase. Similar findings were presented in another study which examined $a$-glucosidase inhibitory effects of different fractions of three species of Labiatae extracts. The study reported no relationship between the concentration level (in some fractions) and enzyme inhibition $^{28}$. Amaranthus hybridus showed opposite results whereby wild samples showed potent $\alpha$-glucosidase inhibitory activity at all concentrations tested, with $89.92 \pm 0.04 \%$ inhibition recorded at the lowest concentration $(0.125 \mathrm{mg} / \mathrm{mL})$. In contrast, the best activity for the cultivated $A$. hybridus $(79.19 \pm 0.13 \%)$ was obtained at a high extract concentration of $1 \mathrm{mg} / \mathrm{mL}$. The results for $A$. hybridus correlate with findings from Chauhan and colleagues ${ }^{29}$ which also showed that the wild variety of the plant shows more inhibition as compared to the cultivated Rauwolfia serpentine.

With regard to $\alpha$-amylase enzyme inhibition, all the extracts (wild and cultivated) of A. hybridus and A. cruentus were weak inhibitors. This is in line with earlier reports which showed that plant phytochemicals of A. cruentus and Zea mays were mild $\alpha$-amylase inhibitors ${ }^{26,30}$. Contrary to this study, although the extracts were tested at higher concentrations ( $3 \mathrm{mg} / \mathrm{mL})$, Odhav and colleagues ${ }^{31}$ reported that $A$. hybridus inhibited a-amylase enzyme by $52.76 \%^{31}$. Moreover, in another study, $A$. cruentus exhibited the highest inhibitory value of $55.40 \%$ at plant extract concentration of $100 \mathrm{mg} / \mathrm{Ml}^{32}$. In a separate study, although the authors reported on different species than the ones utilized in this study, Conforti and colleagues ${ }^{33}$ demonstrated that methanol, ethyl acetate and hexane extracts from two varieties of $A$. caudatus seeds showed $\alpha$-amylase inhibitory activity (above $80 \%$ inhibition rate) at $0.25-1 \mathrm{mg} / \mathrm{mL}^{33}$.

The combined ethyl acetate extract of the leaves of $A$. cruentus yielded a-spinasterol ${ }^{34}$, palmitic acid ${ }^{35}$, and pheophorbide A-methyl ester ${ }^{36}$. Pheophorbide A-methyl ester has been isolated from A. cruentus for the first time. $\alpha$-Spinasterol inhibited $\alpha$-glucosidase $(80.06 \pm 0.04 \%)$ at highest concentration tested $(1 \mathrm{mg} / \mathrm{mL})$. Several studies have shown promising results for $\alpha$-spinasterol in various antidiabetic assays. In a study by Chukwujekwu and co-workers ${ }^{37}, \alpha$-spinasterol isolated from the leaves of Buddleja saligna showed a-glucosidase enzyme inhibition with $\mathrm{IC}_{50}$ value of $10.7 \mu \mathrm{g} / \mathrm{mL}$. In another study, $\alpha$-spinasterol was reported as a moderate inhibitor of $\alpha$-glucosidase $\left(\mathrm{IC}_{50}=200 \mu \mathrm{M}\right)^{38}$. In a different antidiabetic assay model, $\alpha$-spinasterol was found to ameliorate the development and progression of diabetic nephropathy in streptozotocin-induced diabetic mice.

There are no previous reports, about the inhibitory activity of pheophorbide A-methyl ester on $\alpha$-glucosidase and $\alpha$-amylase in vitro. The best activity $(75.41 \pm 0.03 \%)$ was obtained at $0.5 \mathrm{mg} / \mathrm{mL}$ against a-glucosidase. This is in support of results reported by Kim et al. (2019) that pheophorbide A, an unesterified analog isolated from Gelidium amansii caused significant decrease in the activity of a-glucosidase and $\alpha$-amylase when compared to Acarbose ${ }^{40}$. Palmitic acid showed the best $\alpha$-glucosidase activity in all the concentrations tested ranging from 324.69-355.89 $\mu \mathrm{M}$. These results are comparable with findings reported by Cherigo and Martínez-Luis (2018) in which palmitic acid showed $\alpha$-glucosidase inhibitory activity of $237.5 \mu \mathrm{M}^{41}$. The authors reported that palmitic acid inhibited the activity of $\alpha$-glucosidase enzyme and its activity was similar to acarbose $(241.6 \mu \mathrm{M})$. In the same study, the authors established that palmitic acid acted as a competitive inhibitor and that the compound binds to the same site as acarbose does in the human intestines ${ }^{41}$. In another study, it was found that palmitic acid showed a moderate inhibitory effect on both $\alpha$-amylase and $\alpha$-glucosidase activities at concentrations of $3000 \mu \mathrm{M}$ and $750 \mu \mathrm{M}$ respectively ${ }^{42}$.

Pheophorbide A-methyl ester; palmitic acid and $\alpha$-spinasterol were weak inhibitors of the $\alpha$-amylase enzyme. However, when the 
compounds were tested as a mixture, their activity was enhanced. Thus, the study proposes that the synergistic effects as well as individual activity of phytochemicals in vegetables are responsible for their potent antidiabetic activities, and that the benefit of a diet rich in vegetables is attributed to the complex mixture of phytochemicals present in whole foods. Although the mechanism of action for enzyme inhibition was not determined in this study, it is possible that compounds isolated from $A$. cruentus can either bind to the enzyme at a catalytic site ${ }^{43}$ or can act as a non-competitive inhibitor ${ }^{44,45}$. In other cases, compounds can act as competitive inhibitors ${ }^{46}$.

\section{CONCLUSION}

In line with an old adage by Hippocrates, "Let food be thy medicine, and medicine thy food", an inclusion of Amaranthus crop in people's diets, not only provides minerals and micronutrients, but according to the findings of this study, the crop has medicinal properties. Strong $\alpha$-glucosidase activity inhibition and mild $\alpha$-amylase activity inhibition of Amaranthus extracts and compounds could address the major disadvantages of currently used $\alpha$-glucosidase and $\alpha$-amylase inhibitors which are associated with side effects such as abdominal discomfort, flatulence, and possibly diarrhea. The high a-glucosidase and low $a$-amylase enzyme inhibition observed in this study is beneficial since excessive inhibition of $a$-amylase enzyme might result in abdominal discomfort due to undigested starch linked to high $a$-amylase inhibitory activity. The findings of this study showed that effective, cost-saving therapy using traditional vegetables could be a means of reducing untreated diabetes problems. This study is the first to report the isolation of pheophorbide A-methyl ester from Amaranthus spp. as well as its $\alpha$-glucosidase inhibiting activity.

\section{FUNDING}

This research was funded by the National Research Council (NRF), grant number 102504 and the University of South Africa.

\section{APPENDIX}

Supporting information consisting the NMR spectra of the isolated compounds are included in the appendix file.

\section{REFERENCES}

1. Maseko I, Mabhaudhi T, Tesfay S, Araya HT, Fezzehazion M, Du Plooy CP. African Leafy Vegetables: A review of status, production and utilization in South Africa. Sustainability. 2017;10:1-16. https:// doi.org/10.3390/su10010016.

2. Balasubramanian $T$, Karthikeyan $M$. Therapeutic effect of Amaranthus hybridus on diabetic nephropathy. J Develop Drugs. 2016; 5: 147. 10.4172/2329-6631.1000147.

3. Siwale D, Goma FM, Prasher L, Nyirenda S. Determining blood glucose lowering effects of leaf extracts of Cleome gynandra, Amaranthus cruentus and their mixture in normoglycaemic and hyperglycaemic (Alloxan-diabetic) rats. Journal of Preventive and Rehabilitative Medicine. 2019; 1: 80-5. 10.21617/jprm.2019.0102.2

4. Saeedi P, Petersohn I, Salpea P, Malanda B, Karuranga S, Unwin N, et al. Global and regional diabetes prevalence estimates for 2019 and projections for 2030 and 2045: Results from the International Diabetes Federation Diabetes Atlas. Diabetes Research and Clinical Practice. 2019: 1-10.

5. Telagari M, Hullatti K. In vitro a-amylase and a-glucosidase inhibitory activity of Adiantum caudatum Linn. and Celosia argentea Linn. extracts and fractions. Int. J. Pharmacol. 2015; 47: 425-29.

6. Mumtaz MW, Al-Zuaidy MH, Abdul Hamid A, Danish M, Akhtar MT, Mukhtar $\mathrm{H}$. Metabolite profiling and inhibitory properties of leaf extracts of Ficus benjamina towards $\alpha$-glucosidase and $\alpha$-amylase. Int. J. Food Prop. 2018; 21: 1560-74. https://doi.org/10.1080/1094 2912.2018.1499112.
7. Thilagam E, Parimaladevi B, Kumarappan C, Mandal SC. $\alpha$-Glucosidase and $\alpha$-amylase inhibitory activity of Senna surattensis. J Acupunct Meridian Stud. 2013; 6: 24-30.

8. Asche C, McAdam-Marx C, Shane-McWhorter L, Sheng X, Plauschinat C. Association between oral antidiabetic use, adverse events and outcomes in patients with type 2 diabetes. Diabetes Obes Metab. 2008; 10: 638-45.

9. Wang $H$, Du YJ, Song HC. $\alpha$-Glucosidase and $\alpha$-amylase inhibitory activities of guava leaves. Food Chem. 2010; 123: 6-13.

10. Kumar D, Gupta N, Ghosh R, Gaonkar RH, Pal BC. a-Glucosidase and $\alpha$-amylase inhibitory constituent of Carex Baccans: Bio-assay guided isolation and quantification by validated RP-HPLC-DAD. J. Funct. Foods. 2013; 5: 211-18.

11. Yin Z, Zhang W, Feng F, Zhang Y, Kang W. $\alpha$-Glucosidase Inhibitors isolated from medicinal plants. Food Sci Hum Well. 2014; 3: 13674.

12. Arise RO, Yekeen AA, Ekun OE. In vitro antioxidant and a-amylase inhibitory properties of watermelon seed protein hydrolysates. Environ. Exp. Bot. 2016; 14: 163-72.

13. Adisakwattana $S$, Ruengsamran $T$, Kampa $P$, Sompong W. In vitro inhibitory effects of plant-based foods and their combinations on intestinal $\alpha$-glucosidase and pancreatic $\alpha$-amylase. BMC Compl Alternative Med. 2012; 12: 1-8.

14. Hargrove JL, Greenspan P, Hartle DK, Dowd C. Inhibition of aromatase and $\alpha$-amylase by flavonoids and proanthocyanidins from Sorghum bicolor bran extracts. J. Med. Food. 2011; 14: 799807.

15. Shaik K, Shaik AFS, Kumar DEE, Kadirvel D. Evaluation of preliminary phytochemical properties and hypoglycemic activity of Cleome gynandra L. Int J Pharm Pharm Sci. 2013; 5: 824-28.

16. Sathya J, Parimala M, Shoba FG. Identification of glucosidases inhibitory potential from Citrullus lanatus seed extract. Phytochem. 2015; 3: 12-14

17. Ademiluyi AO, Oboh G, Aragbaiye FP, Oyeleye SI, Ogunsuyi O.B. Antioxidant properties and in vitro a-amylase and a-glucosidase inhibitory properties of phenolics constituents from different varieties of Corchorus spp. J. Taibah Univ. Medical Sci. 2015; 10 : 278-87.

18. Oboh G, Ademiluyi AO, Akinyemi AJ, Henle T, Saliu JA, Schwarzenbolz $\mathrm{U}$. Inhibitory effect of polyphenol-rich extracts of jute leaf (Corchorus olitorius) on key enzyme linked to type 2 diabetes ( $\alpha$-amylase and $\alpha$-glucosidase) and hypertension (Angiotensin converting) in vitro. J. Funct. Foods. 2012; 4: 450-458.

19. Kasozi KI, Namubiru S, Safiriyu AA, Ninsiima HI, Nakimbugwe D, Namayanja M, et al. Grain amaranth is associated with improved hepatic and renal calcium metabolism in type 2 diabetes mellitus of male Wistar rats. J Evid Based Complementary Altern Med. 2018: 1-10. https://doi.org/10.1155/2018/4098942.

20. Balasubramanian $T$, Karthikeyan $M$, Muhammed Anees KP Kadeeja CP, Jaseela K. Antidiabetic and antioxidant potentials of Amaranthus hybridus in streptozotocin-induced diabetic rats. J. Diet. Suppl. 2017; 14: 395-410. https://doi.org/10.1080/19390211 .2016.1265037.

21. Ghosh D, Mitra P, Ghosh T, Mitra PK. Anti peptic ulcer activity of the leaves of Amaranthus spinosus L. in rats. Pharmacology. 2008; 40: 126-131.

22. Sasikumar V, Subramaniam A, Aneesh A, Saravanan G. Protective effect of alkaloids from Amaranthus viridis Linn. against hydrogen peroxide induced oxidative damage in human erythrocytes (RBC). Clin. Endocrinol. 2015; 1: 49-53.

23. Esikhawini climate, Map of South Africa, nd, viewed 19 December 2019, http://www.saexplorer.co.za/south-africa/climate/esikhawini_climate.asp 
24. Stanger climate, Map of South Africa, nd, viewed 19 December 2019, http://www.saexplorer.co.za/south-africa/climate/stanger_ climate.asp

25. Mulandana NS, Mamadi NE, Du Plooy CP, Beletse YG. Effect of spacing and transplanting time on Amaranths yield. Afr. Crop Sci. J. 2009; 9: 243-46.

26. Oboh G, Akinyemi AJ, Ademiluyi AO, Bello FO. Inhibition of a-amylase and $\boldsymbol{\alpha}$-glucosidase activities by ethanolic extract of Amaranthus cruentus leaf as affected by blanching. J. Pharm. Pharmacol 2013; 7: 1026-32.

27. Mondal A, Guria T, Maity TK. A new ester of Fatty acid from a methanol extract of the whole plant of Amaranthus spinosus and its a-glucosidase inhibitory activity. Pharm. Biol. 2015; 53: 600-04.

28. Rouzbehan S, Moein S, Homaei A, Moein MR. Kinetics of a-glucosidase inhibition by different fractions of three species of Labiatae extracts: a new diabetes treatment model. Pharm. Biol 2017; 55: 1483-88. https://doi.org/10.1080/13880209.2017.13065 69.

29. Chauhan S, Kaur A, Vyas M, Khatik GL. Comparison of antidiabetic and antioxidant activity of wild and cultivated variety of Rauwolfia serpentina. Journal of Pharmacology \& Clinical Research. 2017 ; 10(12): 404-6. https://doi.org/10.22159/ajpcr.2017.v10i12.21287.

30. Kwon YI, Apostolidis E, Kim YC, Shetty K. Health benefits of traditional corn, beans, and pumpkin: In vitro studies for hyperglycemia and hypertension management. J. Med. Food 2007; 10: 266-75.

31. Odhav B, Kandasamy T, Khumalo N, Baijnath H. Screening of African traditional vegetables for their alpha-amylase inhibitory effect. J. Med. Plants Res 2010; 4: 1502-07.

32. Ramalashmi K. In vitro antidiabetic potential and GC-MS analysis of Digera muricata and Amaranthus cruentus. J. Med. Plants 2019; 7: 10-16. https://doi.org/10.1155/2018/4098942.

33. Conforti F, Statti G, Loizzo MR, Sacchetti G, Poli F, Menichini F. In vitro antioxidant effect and inhibition of $\alpha$-amylase of two varieties of Amaranthus caudatus seeds. Biol. Pharm. Bull 2005; 28: 10981102.

34. Kojima H, Sato N, Hatano A, Ogura H. Sterol glucosides from Prunella vulgaris. Phytochemistry. 1990; 29: 2351-55.
35. Bulama JS, Dangoggo SM, Halilu ME, Tsafe Al, Hassan SW. Isolation and characterization of palmitic acid from ethyl acetate extract of root bark of Terminalia glaucescens. J Cardiovasc Magn Reson 2014; 6: 140-43.

36. Rho MC, Chung MY, Song HY, Kwon OE, Lee SW, Baek JA, et al Pheophorbide a-methyl ester, acyl-coa: cholesterol acyltransferase inhibitor from Diospyros kaki. Pharmacal Res. 2003; 26: 716-18.

37. Chukwujekwu JC, Rengasamy KR, de Kock CA, Smith PJ, Slavětínská LP, van Staden J. Alpha-glucosidase inhibitory and antiplasmodial properties of terpenoids from the leaves of Buddleja saligna Willd. J. Chem. 2016; 31: 63-66.

38. Jeong SY, Nguyen PH, Zhao BT, Ali MY, Choi JS, Min BS, et al. Chemical constituents of Euonymus alatus (Thunb.) Sieb. and their PTP1B and a-glucosidase inhibitory activities. Phytother Res. 2015; 29: $1540-48$

39. Jeong SI, Kim KJ, Choi MK, Keum KS, Lee S, Ahn SH, et al. $\alpha-S p i n a s t e r o l$ isolated from the root of Phytolacca americana and its pharmacological property on diabetic nephropathy. Planta Med. 2004; 70: 736-39.

40. Kim MJ, Kim HJ, Han JS. Pheophorbide A from Gelidium amansii improves postprandial hyperglycemia in diabetic mice through $\alpha$ glucosidase inhibition. Phytother Res. 2019; 33: 702-07. https://doi. org/10.1002/ptr.6260.

41. Cherigo L, Martínez-Luis S. a-Glucosidase inhibitor isolated from Blechum pyramidatum. Nat Prod Commun. 2018; 13: 461-64. https://doi.org/10.1177\%2F1934578X1801300421.

42. Su CH, Lai MN, Ng LT. Inhibitory effects of medicinal mushrooms on a-amylase and $\alpha$-glucosidase-enzymes related to hyperglycemia. Food Funct. 2013; 4: 644-49. https://doi.org/10.1039/C3FO30376D.

43. Escandón-Rivera S, González-Andrade M, Bye R, Linares $E$, Navarrete A, Mata R. a-Glucosidase inhibitors from Brickellia cavanillesii. J. Nat. Prod. 2012; 75: 968-74.

44. Kim SD. a-Glucosidase inhibitor from Buthus martensi Karsch. Food Chem. 2013; 136: 297-300. https://doi.org/10.1021/np300204p.

45. Wang ZW, Wang JS, Luo J, Kong LY. a-Glucosidase inhibitory triterpenoids from the stem barks of Uncaria laevigata. Fitoterapia. 2013; 90: 30-37.

46. Kang W, Zhang L, Song Y. Alpha-glucosidase inhibitors from Rubia cordifolia. China Journal of Chinese Materia Medica. 2009; 34: 1104-07.

\section{GRAPHICAL ABSTRACT}

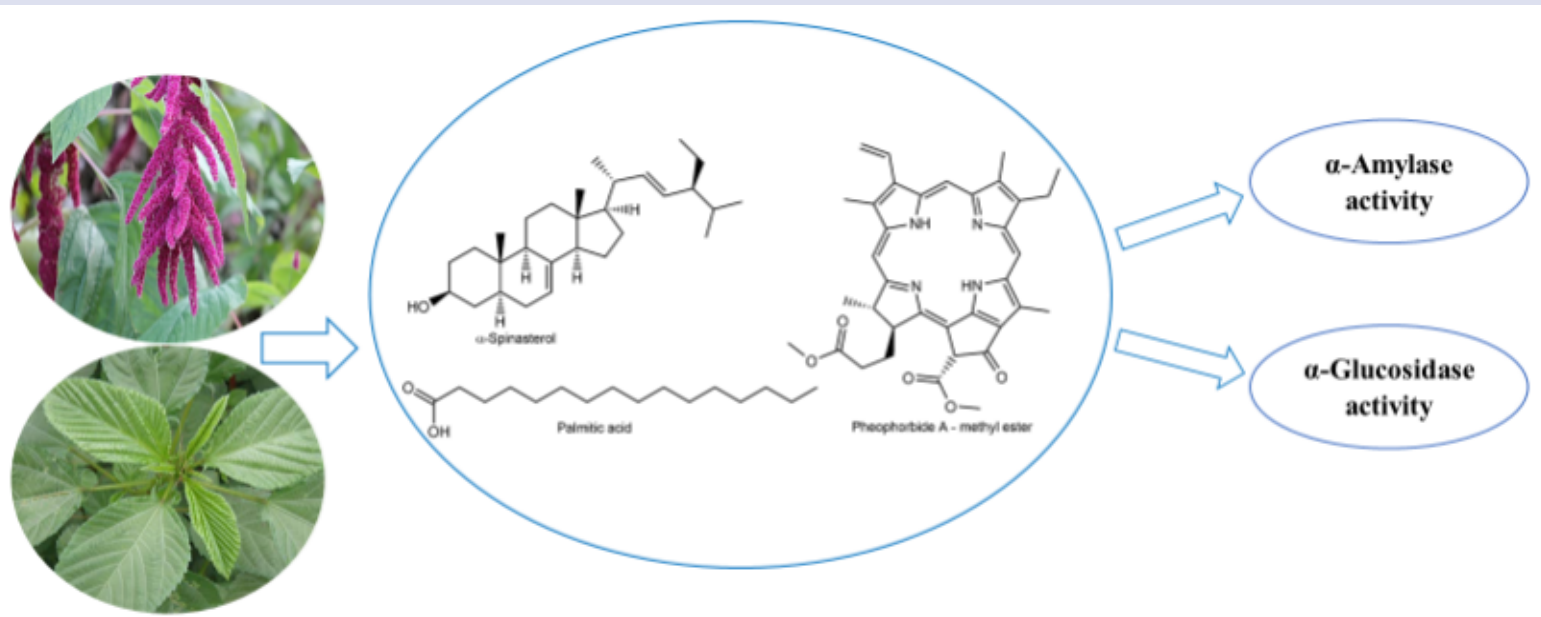




\section{ABOUT AUTHORS}

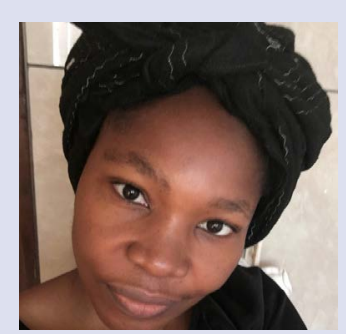

Nolitha Nkobole: Lecturer in the Department of Agriculture and Animal Health, University of South Africa.

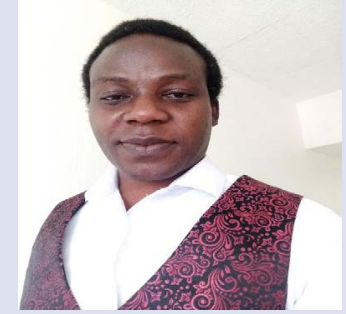

Olusola Bodede: Post-doctoral researcher in the Department of Agriculture and Animal Health, University of South Africa.

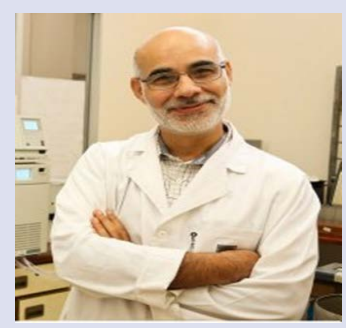

Ahmed Mohammed Hussein: Professor in the Department of Chemistry, Cape Peninsular University of Technology.

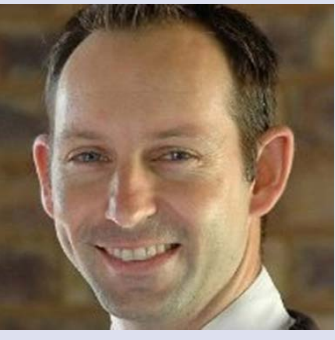

Gerhard Prinsloo: Professor in the Department of Agriculture and Animal Health, University of South Africa.

Cite this article: Nkobole N, Bodede O, Hussein AA, Prinsloo G. In vitro $\alpha$-Glucosidase and $\alpha$-Amylase Activities of Wild and Cultivated Amaranthus spp. and Isolated Compounds. Pharmacogn J. 2021;13(6)Suppl: 1614-1620. 